Research, part of a Special Feature on Exploring Opportunities for Advancing Collaborative Adaptive Management (CAM): Integrating Experience and Practice

\title{
Integrating Collaboration, Adaptive Management, and Scenario- Planning: Experiences at Las Cienegas National Conservation Area
}

\author{
$\underline{\text { Jeremy K. Caves }}^{1}$, Gitanjali S. Bodner $^{2}, \underline{\text { Karen Simms }}^{3}$, Larry A. Fisher $^{4}$ and Tahnee Robertson $^{5}$
}

ABSTRACT. There is growing recognition that public lands cannot be managed as islands; rather, land management must address the ecological, social, and temporal complexity that often spans jurisdictions and traditional planning horizons. Collaborative decision making and adaptive management (CAM) have been promoted as methods to reconcile competing societal demands and respond to complex ecosystem dynamics. We detail the experiences of land managers and stakeholders in using CAM at Las Cienegas National Conservation Area (LCNCA), a highly valued site under the jurisdiction of the Bureau of Land Management (BLM). The CAM process at Las Cienegas is marked by strong stakeholder engagement, with four core elements: (1) shared watershed goals with measurable resource objectives; (2) relevant and reliable scientific information; (3) mechanisms to incorporate new information into decision making; and (4) shared learning to improve both the process and management actions. The combination of stakeholder engagement and adaptive management has led to agreement on contentious issues, more innovative solutions, and more effective land management. However, the region is now experiencing rapid changes outside managers' control, including climate change, human population growth, and reduced federal budgets, with large but unpredictable impacts on natural resources. Although the CAM experience provides a strong foundation for making the difficult and contentious management decisions that such changes are likely to require, neither collaboration nor adaptive management provides a sufficient structure for addressing the externalities that drive uncontrollable and unpredictable change. As a result, LCNCA is exploring two specific modifications to CAM that may better address emerging challenges, including: (1) creating nested resource objectives to distinguish between those objectives that may be crucial to maintaining ecological resilience from those that may hinder a flexible response to climate change, and (2) incorporating scenario planning into CAM to explore how climate change may interact with other drivers and alter options for the future, to identify robust management actions, and to prioritize ecological monitoring efforts. The experiences at LCNCA demonstrate how collaboration and adaptive management can be used to improve social and environmental outcomes and, with modifications, may help address the full range of complexity and change that threatens to overwhelm even the best efforts to sustain public lands.

Key Words: biological planning; Bureau of Land Management; climate adaptation; collaboration; desert Southwest; ecological monitoring; implementing adaptive management; nested objectives; public lands management; scenario planning;

\section{INTRODUCTION}

Federal public lands comprise nearly 650 million acres and almost $30 \%$ of the U.S. This number nearly doubles when including lands under state or local jurisdictions. The core challenge for public land managers is to sustain in perpetuity the public benefits these lands provide, from resource harvest to biodiversity protection, watershed function to recreational opportunities. This mandate often places public land managers in the middle of political and legal battles between various interests (local/national, corporate/private, motorized recreation/ wilderness advocates, extractive uses/preservationists) who perceive themselves to benefit differentially from alternate management priorities. Because ecosystem management involves decision making within extremely complex natural and social dynamics, the outcomes of management actions are highly unpredictable. Federal land managers must attempt to meet this mandate with declining annual budgets that currently range from US\$3.79 per acre (Bureau of Land Management 2009, U.S. Senate 2009a) to US\$32.73 per acre (National Park
Service 2012). A handful of staff trained in natural resources are often responsible for a thousand square miles or more.

Traditional management paradigms that expect agency staff to single-handedly produce optimal outcomes for all people over all time spans are poorly suited to the reality of these challenges, yet these approaches continue to dominate agency cultures (Shindler and Cheek 1999). In contrast, collaborative decision-making approaches are being increasingly promoted by agencies and stakeholders as a way to navigate competing demands (Johnson 1999, U.S. Government 2004, Bureau of Land Management 2009, U.S. Senate 2009b). Similarly, adaptive management approaches that recognize uncertainty of outcomes and provide mechanisms for responding to changes observed on the ground have begun to be applied more broadly as an effective way of working with ecological complexity (Holling 1978, Walters and Holling 1990, Gunderson 1999, Johnson 1999, Folke et al. 2005, Williams et al. 2009). Many practitioners have attempted to combine

\footnotetext{
${ }^{1}$ Department of Environmental Earth System Science, Stanford University, ${ }^{2}$ The Nature Conservancy, Tucson, Arizona, ${ }^{3}$ Tucson Field Office, Bureau of Land Management, ${ }^{4}$ School of Natural Resources and the Environment, University of Arizona, ${ }^{5}$ Southwest Decision Resources
} 
these approaches, with various branches of policy and research now trying to promote principles of both and understand what attributes make them work well together (Gunderson and Holling 2002, Armitage et al. 2007, 2009, Pomeroy 2007, Plummer 2009, Williams et al. 2009). Combining collaboration and adaptive management is viewed as a way of broadening the scope of information and options considered in decision cycles, instilling accountability into the inherently flexible processes of adaptive management, promoting shared learning, and generating "social license" for managers to try bold solutions to seemingly intractable problems (Schindler and Cheek 1999, Pahl-wostl et al. 2007, Williams et al. 2009, Polasky et al. 2011, Childs et al. 2013).

We describe the experiences of managers and stakeholders who are working to sustain a broad range of natural and cultural resources and associated public benefits in one high-profile southern Arizona valley. Our paper is composed of two parts: we describe the history, evolution, and philosophy of CAM at Las Cienegas, and show that a practical, user-oriented version of CAM has yielded many positive environmental and societal results. We highlight four core elements that have proven essential to implementing CAM and enabled participants to respond to changing conditions on the ground: (1) shared watershed goals with measurable resource objectives; (2) efforts to gather increasingly relevant and reliable scientific information; (3) mechanisms to incorporate new information into decision making; and (4) shared learning to improve both the process and management actions. We discuss external challenges, including climate shifts and other potentially rapid changes that are outside the control of local managers, that may affect ecosystem resiliency and even the collaborative effort itself. We describe efforts being undertaken to modify CAM to anticipate these externalities, including adding new tools such as scenario planning and developing an innovative "nested objective" structure that reconciles adaptive management's need for measurable objectives with the recognition that climate shifts may be creating ecosystem conditions with no analog in the site's history. We also discuss the theoretical lessons from our experiences at Las Cienegas and propose that a combination of collaboration, adaptive management, and scenario planning can more fully address the range of ecological, societal, and temporal complexity that face public lands.

\section{BACKGROUND}

\section{Location}

Fifty miles southeast of the metropolitan area of Tucson, Arizona (population: one million), lies the 300,000-acre Cienega watershed, a broad, $4000 \mathrm{ft}$. high grassland valley suspended between four forested "sky island" mountain ranges (Fig. 1). Much of the upper watershed is under the jurisdiction of BLM and designated as a National Conservation Area. Las Cienegas National Conservation Area
(LCNCA) includes some 50,000 acres of public land administered by BLM plus an additional 50,000 acres of State Trust Land on which BLM holds the state grazing leases. Management of LCNCA therefore influences land health across much of the upper watershed, which is vital to the Tucson metropolitan area for flood control and aquifer recharge (Keith 1981, Knight 1996, Fonseca 2008).

Cienega Creek flows north along the bottom of the valley into the Tucson basin. At the south end of the watershed, in an area commonly called the Sonoita Valley, a low divide separates surface water flow between Cienega Creek and the upper watersheds of Sonoita Creek (tributaries of the Santa Cruz River) and the Babocomari River (a tributary of the San Pedro River). All three creeks have sections that flow year-round, rare sources of perennial surface water in a semiarid landscape (Pima County Board of Supervisors 1999, Pima Association of Governments 2000) and an indicator of both near-surface groundwater and a relatively healthy watershed that is able to capture and slowly release rainfall (Bota 1997, Fonseca 2008).

LCNCA supports several threatened and endangered species and five of the rarest plant communities in the Southwest: cienega wetlands, cottonwood-willow riparian forests, sacaton grasslands, mesquite bosques, and semidesert grasslands. In conjunction with lands managed by the U.S. Forest Service, Pima County, the Department of Defense, and numerous private landowners with conservation easements, the LCNCA's grasslands and woodlands maintain connectivity among several of the region's sky island mountain ranges and play a vital role in regional wildlife linkages (Beier et al. 2006). The Cienega Watershed and the Sonoita Valley are also renowned for their archaeological and more recent western cultural heritage (Swanson 1951, Dowell 1978, Eddy and Cooley 1983, Majewski 2004). The landscape's natural resources continue to support a thriving rural community concentrated around the town of Sonoita and scattered in pockets of private land throughout the valley. Management of the LCNCA is multiuse and includes active livestock grazing as well as a variety of recreational activities.

\section{History of collaborative adaptive management at LCNCA}

The Sonoita Valley has a long history of public engagement. Local residents advocated for the land exchange that eventually brought private lands into public ownership as the BLM Empire-Cienega Resource Conservation Area in 1988. Prior to this, the lands faced an uncertain future that most likely included development for housing or water extraction for mining. Following the 1988 land acquisition, BLM initiated a traditional planning process to develop the required land use plan. The process stalled after several years because of a combination of changing agency priorities, limited public participation opportunities, and increasing polarization and 
Fig. 1. Location map.

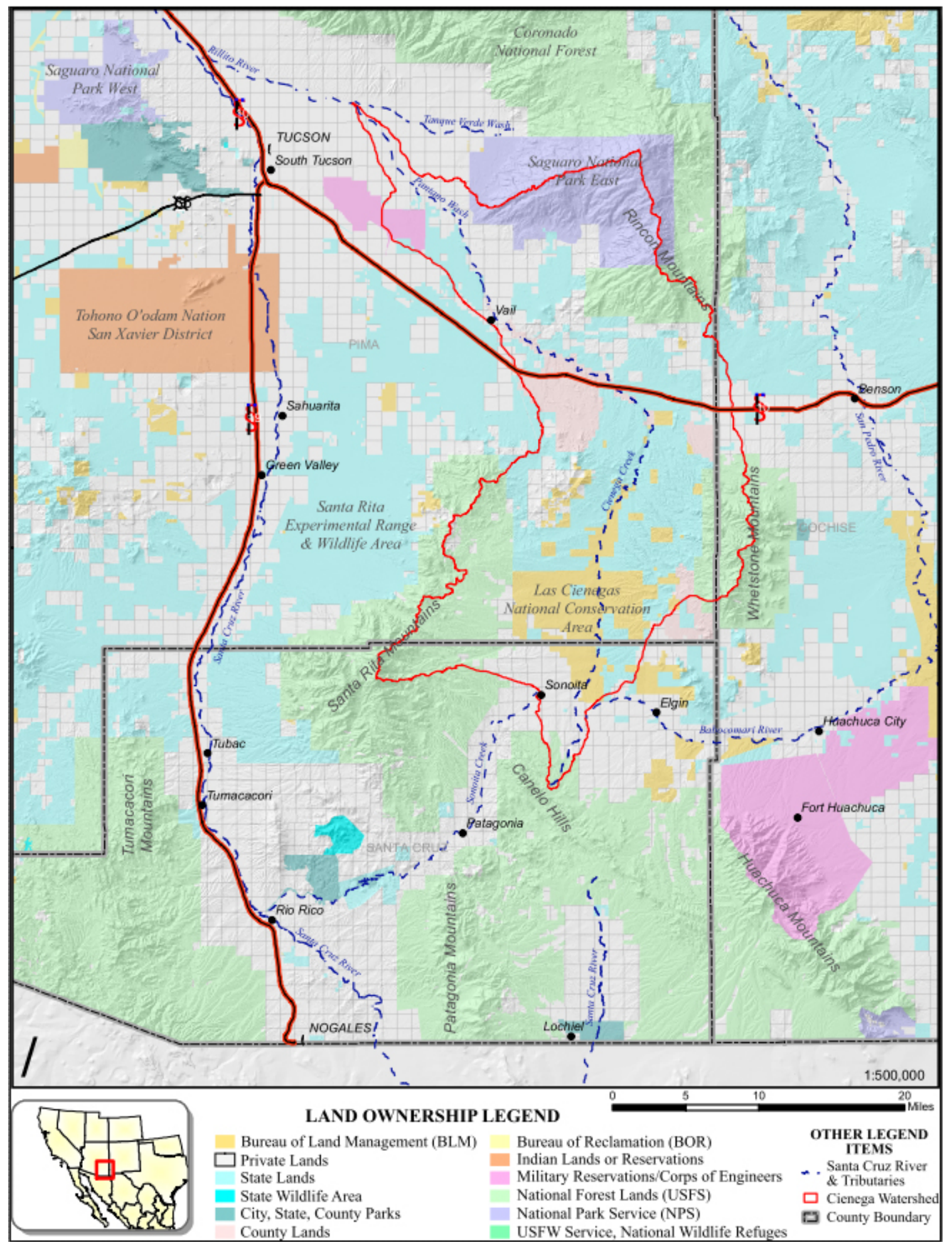


Fig. 2. A timeline of important milestones and the evolution of collaborative adaptive management (CAM) at Las Cienegas National Conservation Area. BLM = Bureau of Land Management; SVPP = Sonoita Valley Planning Partnership; CAMNet $=$ Collaborative Adaptive Management Network.

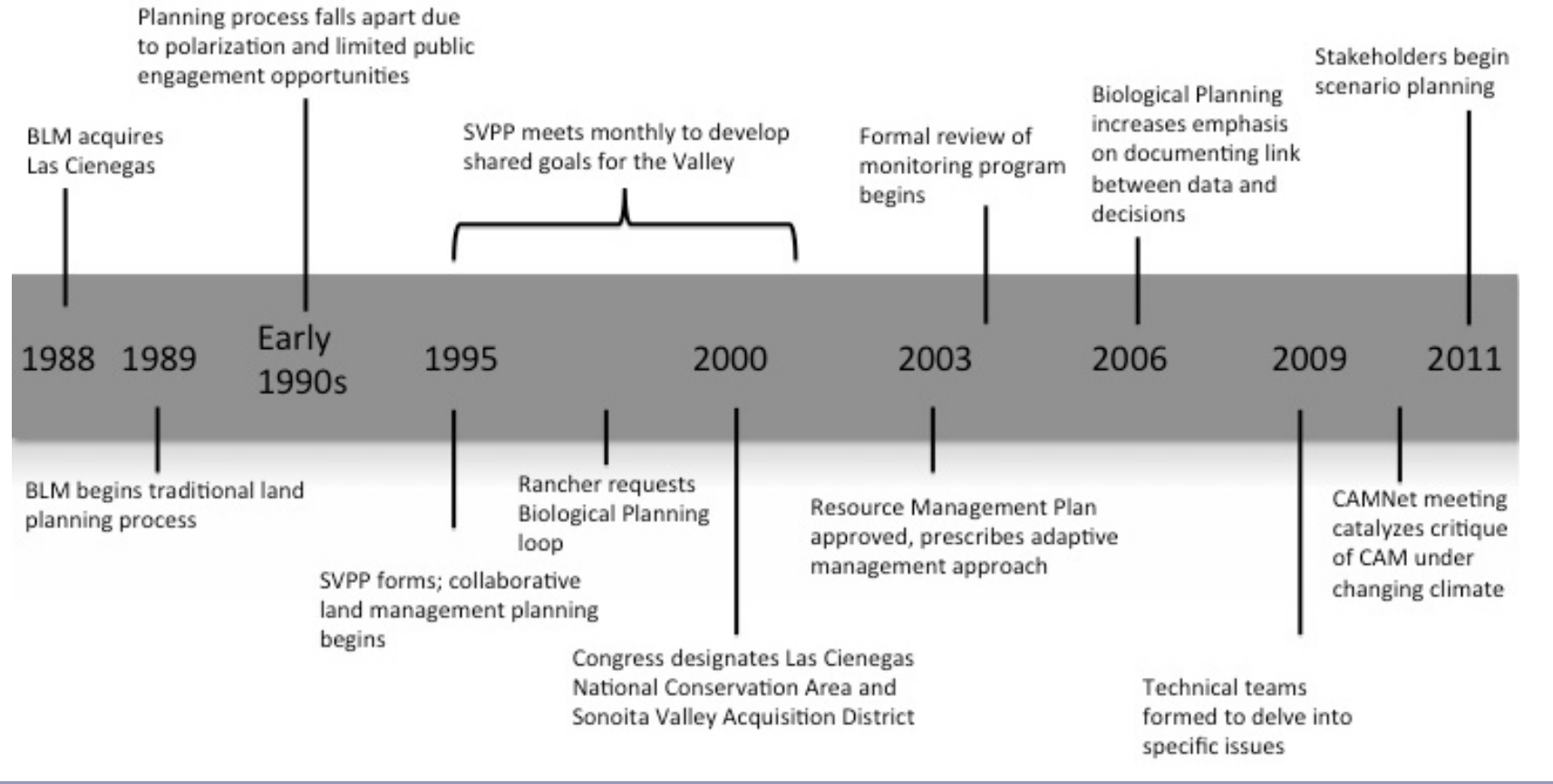

divisiveness over issues such as mining, livestock grazing, recreation use, and wildlife management.

Because this initial planning effort frustrated stakeholders who felt they were unable to meaningfully participate, in 1995 the BLM Field Manager decided to initiate a collaborative process for developing the site's resource management plan (RMP), encouraging more extensive public engagement, guided by the principles of ecosystem management (Grumbine 1994, Kaufmann et al. 1994, Christensen et al. 1996, Szaro et al. 1998). BLM employed a neutral facilitator and worked directly with participants to design the planning process, which included a series of open public meetings. Initial meetings led to the formation of the Sonoita Valley Planning Partnership (SVPP), an ad hoc group with participants from more than a dozen communities in southeastern Arizona and representatives of conservation organizations, grazing interests, recreational user groups, and federal, state, and local agencies. SVPP participants embraced the collaborative approach, regularly attending monthly SVPP meetings and more frequent working group meetings. Many SVPP members were part of a successful public campaign that resulted in Congressional designation of National Conservation Area status for the area in 2000.

Later in the planning process, the collaborative group opted to incorporate an adaptive management approach to build in management flexibility and address uncertain outcomes of management actions. The jointly developed RMP (Bureau of Land Management 2003) incorporates this collaborative adaptive management (CAM) approach. This science-based adaptive management program is designed to provide decision makers with reliable and timely information on resource conditions and trends.

The general structure of the LCNCA CAM process, developed incrementally by participants based on evolving needs at the site (timeline summarized in Fig. 2), closely parallels descriptions in theoretical literature (Williams et al. 2009; Fig. $3)$. LCNCA uses shared goals and measurable objectives to guide management actions, an ecological monitoring program to gather information about key resources and to measure progress in meeting RMP objectives, and a biological planning process to incorporate new information into decision making and provide a forum for regular stakeholder engagement. Twice a year, stakeholders meet at LCNCA to discuss results of the monitoring and proposed management actions, as well as research results that might inform these actions. Implementing management actions is largely the responsibility of BLM and the grazing permittee, but other stakeholders contribute substantially with staff and volunteer time as well as grant-funded projects. 
Fig. 3. The collaborative adaptive management process at Las Cienegas National Conservation Area. At most stages of the cycle, stakeholders are actively involved through participation in the semiannual biological planning meetings, volunteering, or participation on a technical team (TT). The four core elements are essential for implementing this loop. We propose incorporating scenario planning as part of the CAM cycle, drawing upon the nested objectives to further refine the design of proposed actions. BLM = Bureau of Land Management; SH = Stakeholder. Note: the Permittee is considered a stakeholder and member of the TTs.

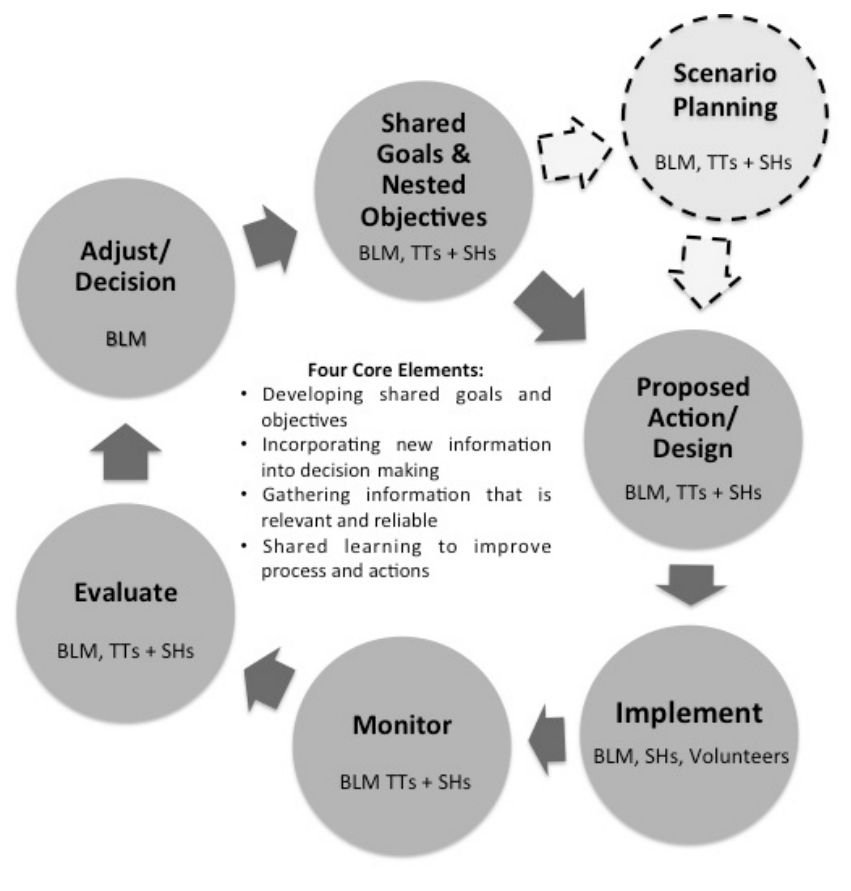

\section{CORE ELEMENTS OF CAM AT LCNCA}

The combination of stakeholder involvement and adaptive management has yielded many benefits at this site, benefits that could not have been attained by either approach in isolation. Each of the following four core elements reflects the philosophy, lessons, and evolution of CAM at LCNCA and involve both stakeholder participation and learning about ecological dynamics.

\section{Developing shared goals and measurable objectives}

Having shared goals and measurable objectives has helped participants move beyond entrenched positions, to problem solve together, and use science as the arbiter of what works. Initially, stakeholders involved in the SVPP planning process focused on their values and concerns about the Sonoita Valley, just as BLM focused on what uses were allowable. Resulting discussions about appropriate land use and resource allocations frequently dominated meetings and at times were quite contentious, as participants advocated for their individual, or their organization's, interests. It soon became apparent that the focus needed to shift from allowable uses to the desired conditions of resources that supported these uses.

Leadership from BLM staff played a large role in this shift, and represents a departure from the agency's traditional focus on permitted uses toward a primary focus on resource conditions. Through a delegated system of authority, BLM line officer decision making has traditionally been organized around approving permitted uses. Las Cienegas planning staff recognized that the agency and stakeholders were unlikely to overcome stalemates unless both sides could bring their common goals to the forefront, and that this meant considering resource conditions ahead of permitted uses. Support from a Field Office Manager who valued creative problem solving endorsed the shift to emphasizing resource condition, which quickly became the foundation upon which both collaboration and adaptive management could grow.

This shift in focus led participants to craft a shared vision, followed by a negotiated agreement on the primary resource goals: maintenance of healthy riparian areas and native grassland systems, and associated water, vegetation, wildlife, and cultural resources. These broad goals support many recreational opportunities, livestock grazing, and other public land uses. The agreement to give priority to resources over uses was pivotal because it allowed the group to move forward in developing specific objectives for the Sonoita Valley and LCNCA, and to ultimately reach agreement on a preferred set of alternative management strategies for resolving issues and achieving those objectives.

Moving from broad shared goals to the development of more specific and quantifiable resource objectives included several steps. SVPP invited technical experts to give a series of educational presentations on the resources and management activities within the area, which helped participants develop a common understanding about these resources. For example, presentations on semidesert grasslands function provided understanding about how to achieve a healthy and diverse vegetation community. Following these educational presentations, working groups drafted objectives for each of the goals using best available science, e.g., data on baseline resource conditions, current state of knowledge on resource and system dynamics, and in some cases ecological models. The group conducted additional field assessments and gathered data to support the development of objectives.

Ultimately, the SVPP revised and finally agreed on the specific, ecologically based, and measurable resource objectives that became the foundation for the CAM process, and for the legislation that created Las Cienegas National 
Conservation Area and Sonoita Valley Acquisition Planning District in 2000 (U.S. Senate 2000). In accordance with the Las Cienegas National Conservation Area Establishment Act, the Las Cienegas RMP included the SVPP's desired future conditions and management strategies as the agency's preferred alternative.

\section{Solid science: gathering relevant and reliable information}

Having reliable information on status and trends of important natural resources has both enhanced stakeholder confidence and improved the link between monitoring and management decisions. BLM began collecting baseline information and establishing monitoring soon after acquiring the lands now within LCNCA, but the program lacked objectives, a plan to guide it, and actual use of the data. In 2000, BLM and stakeholders held an ecological monitoring workshop that generated numerous suggestions (summarized in Bureau of Land Management 2003) but no clear direction forward. The RMP calls for an ecological monitoring program, but BLM initially had trouble adequately resourcing the program to effectively inform adaptive management efforts. In 2004, BLM and stakeholders asked The Nature Conservancy (TNC) to help the group evaluate and refine monitoring targets, protocols, and implementation. Evaluations of monitoring program areas have addressed four main questions:

- Can existing monitoring show whether resource objectives are being met?

- Are results usable by decision makers?

- Do monitoring protocols have adequate power to detect change around critical ecological thresholds?

- Is the proposed monitoring feasible and can it be consistently applied?

LCNCA's upland monitoring protocols provide the most developed examples of how evaluations have refined monitoring (Gori and Schussman 2005, Gori et al. 2010). A review of data being collected on range conditions showed that some measurements were not tied to RMP objectives; other measurements did track objectives but had insufficient sampling intensity to detect important changes around levels believed to be important ecological thresholds (Bestelmeyer 2006, Groffman et al. 2006); and some key ecosystem drivers were not being measured at all. In response, the monitoring protocols were changed to increase sample size for key parameters, decrease effort spent on parameters not tied to objectives, and add periodic tracking of drivers, all while preserving comparability with previous data (Gori et al. 2010). Some modifications took time to be accepted by all parties, but field visits demonstrating that data was capturing important changes boosted acceptance.

Evaluating how managers and stakeholders used monitoring data proved to be as important as evaluating data content.
Mismatches between decision making and information accessibility prompted changes in when data was gathered and how it was shared. For example, the rancher typically made decisions on how many cattle to buy and sell in late October. Making sure that the biological planning group received monitoring results well before these shipping dates improved the group's ability to respond quickly to conditions on the ground. However, even when received in advance of decisions, unanalyzed, minimally summarized data inspired little dialogue. Summarizing and analyzing monitoring results in ways that highlighted changes in key parameters, such as percent bare ground, encouraged the group to discuss areas of concern and suggest options for addressing those concerns (Simms et al. 2006). Such analyses showed, for instance, that areas with high shrub cover often failed to meet perennial grass cover objectives. Visiting such sites in the field and discussing this data in the context of ecological models prompted the group to advocate for implementing more prescribed fire and other vegetation treatment actions proposed in the RMP.

Ecological models (Fig. 4) have been very important in these efforts to refine monitoring, revise objectives, and interpret results with stakeholders. State-and-transition models developed by the Natural Resources Conservation Service (Bestelmeyer et al. 2009) have been especially useful at this site for enhancing communication among stakeholders with varying backgrounds. These models have helped identify ecological thresholds and drivers of change, such as the point at which loss of ground cover tends to dramatically increase soil erosion rates or the role of fire in maintaining open grasslands. Models have occasionally been modified to better meet needs at this site (Tiller et al. 2012). The generalized state-and-transition model has also prompted many discussions about causes and uncertainties in grassland dynamics observed at the site, a shared learning result that has also been observed elsewhere (Knapp et al. 2011a, 2011b).

By modifying measurement methods and timing, the group has been able to tie monitoring more closely to resource objectives, key ecological drivers and thresholds, and agency decision-making cycles. Improved usability of data has, in turn, boosted support for monitoring. Biological planning participants now expect to have and discuss monitoring results at meetings. This serves as an accountability mechanism to ensure consistent data collection and analysis, and further solidify the site's shift in emphasis from allowable uses to maintaining desired resource conditions. As demonstrated elsewhere (e.g., Serrat-Capdevila et al. 2009), putting relevant and reliable science at the table benefits both social dynamics and ecological problem solving.

\section{Incorporating new information into decision making}

By bringing managers and stakeholders together to evaluate new information, the biological planning process provides a crucial mechanism for exploring and responding to changes on the ground. This process convenes participants on a 
Fig. 4. A conceptual model of southern Arizona semidesert grasslands. This model is generalized from numerous models developed for specific ecological sites; value ranges reflect differences in thresholds among specific soil types and plant communities. Such models may also be useful during scenario planning as a tool to understand how changing drivers may alter ecosystem states.

\section{Ecological model}

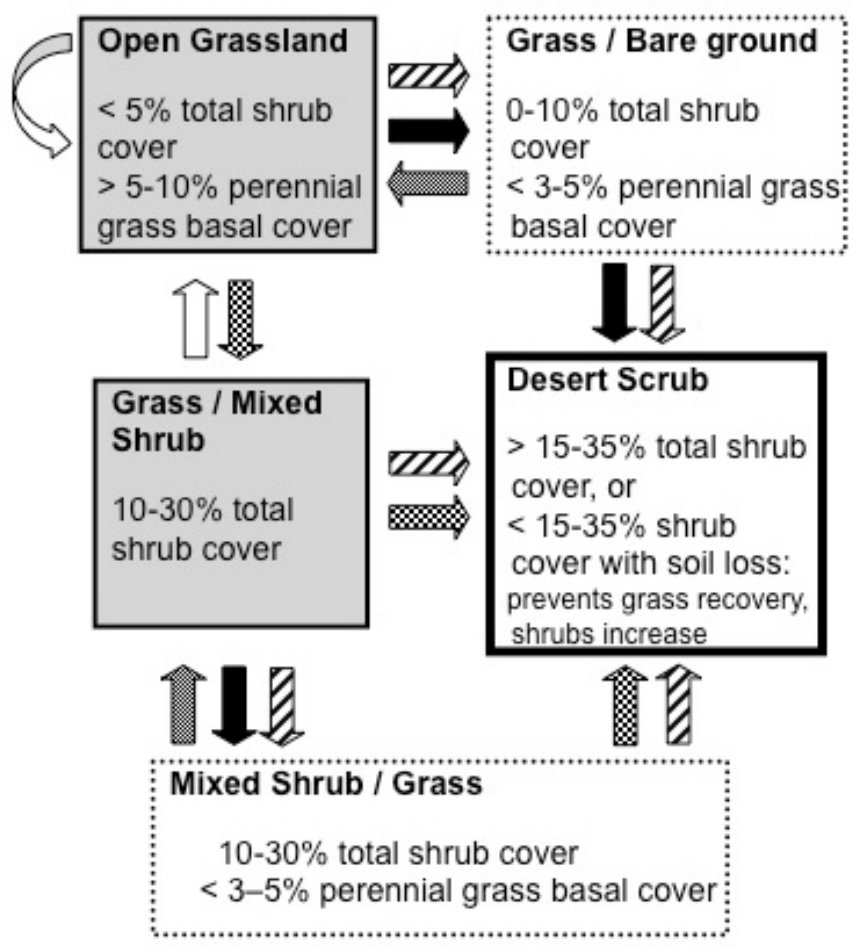

\section{Legend}

\section{Ecosystem states}

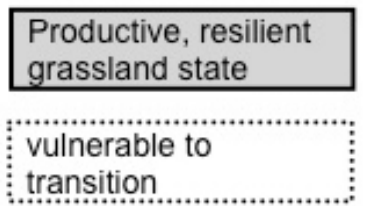

degraded state, hard

to recover

\section{Driving processes}

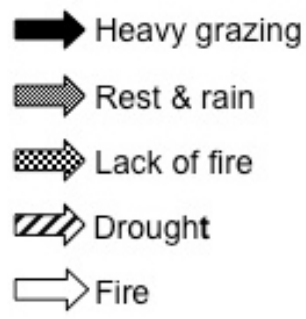

recurring basis to evaluate resource conditions, based on recent monitoring results, research, and field visits, and discuss upcoming decisions and actions. This process has proven to be an effective way of engaging stakeholders in an adaptive management loop for livestock grazing (Simms et al. 2006, Gori et al. 2010). Managers have also sought to broaden the scope of the process beyond its initial focus on livestock grazing management.

BLM and stakeholders have continued to modify the biological planning process to better coordinate and review monitoring results, promote continued high level of stakeholder involvement, and ensure that timely science and an appropriate review process inform BLM decisions. As part of improving the biological planning process, the BLM engaged an independent facilitator, Southwest Decision Resources, through an agreement with U.S. Institute for Environmental Conflict Resolution (USIECR), to evaluate and improve the process. Process changes include production of a newsletter to compile preparatory materials in a more user-friendly format, and making a more concerted effort to document points of contention and agreement in biological planning meetings. Structural changes included formation of four technical teams, i.e., upland areas, riparian areas, heritage resources, and landscape level issues, as well as a coordinating committee with representation from each technical team (http://sites.google.com/site/lcncaadaptivemanagement; Gori et al. 2010). The technical teams are co-coordinated by stakeholders, providing greater opportunity for shared leadership and broader commitment to the collaborative process. The co-coordinators represent their technical team on a coordinating committee that guides the overall process and ensures communication across teams. Each technical team is charged with helping analyze the collected monitoring data and providing input to BLM concerning proposed actions. Further, the technical teams present the analysis and evaluation of monitoring results at the biological planning meetings to educate all stakeholders about the current state of LCNCA and encourage discussion and collaborative problem solving about management challenges and proposed management actions. 
As a result of this progress, discussion at the semiannual meetings has progressively expanded to address other management strategies, such as ecological restoration, endangered species protection, and non-native species control. Discussions and suggestions from biological planning meetings are increasingly being considered in agency decisions. For example, monitoring and field visits of prescribed burn areas culminated in a discussion at one biological planning meeting about when to light prescribed burns. Suggestions from this meeting resulted in an agency decision to not light prescribed fires after particularly dry winters, when fire can kill perennial grasses rather than rejuvenate them. The biological planning process has improved many LCNCA management actions: it has proven an effective forum for stakeholder learning and debate, a mechanism for sharing ideas or concerns regarding implementation, and, most importantly, has helped close the gap between information gathering and decision making.

\section{Embracing shared learning to improve the process and actions}

Stakeholders' desire for more comprehensive understanding of ecosystem and societal dynamics has expanded learning beyond the site's formal monitoring program and biological planning meetings. Meeting notes reveal recurring requests for information that is both broader and more detailed than that provided by the LCNCA monitoring program. This reveals frustration with restricted monitoring budgets as well as stakeholder interest in exploring new information.

To address these concerns, the coordinating committee has invited experts in natural resource fields to brief stakeholders on various technical issues, organized field trips to the LCNCA, and encouraged stakeholders to offer their own expertise through participation in technical teams and workshops. Several State of the Watershed workshops have focused on LCNCA and the Cienega Watershed/Sonoita Valley; technical training has been offered on topics such as arroyo restoration and oral history. Since 2009, an annual "Science on the Sonoita Plain" symposium has provided a forum for researchers to share their work with stakeholders and the interested public (Bodner et al. 2012; summaries available at http://researchranch.audubon.org/Library.html). Organizers have used this event to examine issues that the Biological Planning technical teams are facing, such as appropriate management of ephemeral washes or management and decision-making tools that might be useful to the LCNCA CAM process, and to simply share and celebrate insights into the area's rich natural and cultural heritage.

Such shared learning has helped build agreement on solutions to contentious issues and has better prepared the group to respond to emerging challenges by educating participants about regional trends and dynamics. For instance, when the SVPP first began meeting, some stakeholders were adamantly opposed to a continuation of grazing at LCNCA, while participating ranchers wanted to continue their livelihoods and managers were required to consider multiple use regulations. Through field trips, joint fact-finding, meetings, consultation with subject matter specialists, and a discussion of concerns, those in opposition to grazing recognized that this use could be compatible with RMP objectives for ecosystem health if managed responsibly. Monitoring of range conditions continues and has more recently documented episodic grass cover declines coinciding with prolonged drought conditions. Discussions on field trips with outside resource experts and among stakeholders have revealed similar declines across the region and spurred efforts to test methods for quantifying grass mortality. Including the grazing permittee in these field trips revealed that earlier discussions of drought impacts had alerted him to watch for grass mortality, and he had already adjusted his livestock rotation to avoid areas of higher mortality to promote their recovery.

Although tension remains around participants' desire to know as much as possible about ecological dynamics and the limitations on resources to conduct monitoring and research (Cienega Watershed Partnership, State of the Watershed, unpublished report 2011), participants continue to look for new ways to encourage shared learning among participants, learn more from the work of others, and increase resources available for monitoring and research on the LCNCA.

\section{Accomplishments and ongoing challenges}

More than 15 years of sustained commitment at LCNCA has progressively improved the processes that bring stakeholders together to pursue shared goals, learn more about system dynamics and effects of these actions, and work effectively together to respond to conditions on the ground. Ongoing investments made by both agencies and stakeholder groups testify to the benefits of both good relationships and tangible outcomes on the ground. Many groups have contributed to funding and implementing grassland and riparian restoration projects, developing educational programs, preserving historic sites, and recovering endangered species (Hughes 2010; Cienega Watershed Partnership, State of the Watershed, unpublished report 2011). To date, contentious issues have either been resolved or accepted without legal challenges. Progress made at LCNCA clearly meets the U.S. Department of Interior's criteria for successful adaptive management: "stakeholders are involved and committed to the process; progress is made toward achieving management objectives; results from monitoring and assessment are used to adjust management decisions; and implementation is consistent with applicable laws" (Williams et al. 2009:57).

Others have noted the benefits of this approach. In 2011, managers at the Agua Fria National Monument (AFNM) and two partner agencies (U.S. Forest Service Tonto National Forest and Arizona Game and Fish Department) asked BLM 
staff, stakeholders, and the facilitator from Las Cienegas to help them apply CAM tools to a new management challenge at their own site. Work with the AFNM aims to foster development of the same four core elements at this new site, while allowing the site's stakeholders and managers to tailor both the process and the results to their own needs. Early progress suggests that learning from LCNCA experience is helping this site more quickly solidify agreement on shared goals. Testing new monitoring approaches and coordinated planning mechanisms at AFNM may benefit Las Cienegas as well, developing shared learning opportunities at higher institutional and spatial scales.

In addition to the four core elements described above, a few other enabling factors are important: leadership from a few key participants and ongoing commitment from many others; BLM institutional support and flexibility; and willingness of all parties to vest authority in people dedicated to group problem solving. Although most participants have contributed their time without direct financial compensation, the availability of funding to partners has also catalyzed much progress. Cost-share funding from BLM to partners has provided seed money and/or stop-gap funding for implementation of many projects, including design, collection, and analysis of monitoring data; installation of erosion control structures; habitat improvements for endangered species; and creation of youth stewardship groups. Because partners can carry funding over from one fiscal year to another, and because they invest additional money into these projects, often raising considerable sums from outside sources, funding project work through partners is one of the agency's most effective mechanisms for sustaining implementation of an ambitious management plan despite fluctuations in agency budgets. Nevertheless, having sufficient BLM staff time is also crucial to making use of all this partner investment because agency participation and approval are required at many stages in these projects.

Stakeholder expectations have helped sustain the shift in agency emphasis toward desired resource conditions through staff turnovers in which managers with more traditional use emphasis came and went. Continuity in, and leadership from, key resource staff also buffered the CAM process from such internal changes. Although the agency retains official decision-making authority, instances in which its role has been as a convener more than a decider has actually strengthened those agency decisions by boosting confidence in them. BLM and stakeholders continue to work to guarantee sustained investment of time and funding, quantify the financial, ecological, and social benefits of CAM, and reconcile different mandates among land agencies (Meridian Institute 2010; Cienega Watershed Partnership, State of the Watershed, unpublished report 2010).

Additional challenges, however, remain. Many of these are consistent with critiques of adaptive management in the literature (Walters 1997, Moir and Block 2001, Stankey et al. 2003). Some agency decisions and programs are better suited to stakeholder feedback and the biological planning cycle than others. It is not always clear or well documented how decision makers balance new ecological information with other factors. Limited monitoring resources make it impossible to track all relevant aspects of ecological dynamics, and multiple use management complicates design of experimental research. Like many practitioner sites, LCNCA does not always reach the bar set by adaptive management theory of conducting rigorous experimental testing of multiple hypotheses at the same time (Walters and Holling 1990). However, the LCNCA experience shows that practical, user-created versions of CAM can provide ecological and social benefits even if they do not meet the strict definition laid out in theory, as long as participants continue to strive for improvement.

Beyond these ongoing challenges, stakeholders have recognized future challenges that are largely external to LCNCA, including an uncertain political and budgetary landscape, climate change, and other regional developments. These externalities will challenge the current CAM framework (York and Schoon 2011), which is designed to address issues that are internal to the LCNCA system and controllable through various actions and tools at the manager's disposal. To maintain ecosystem resilience and ensure that this collaborative institution can survive future political, social, and environmental changes and more effectively address externalities will require innovative and flexible responses, new tools, and an evolution of the CAM process, all while retaining the four core elements that have made the process work thus far.

\section{THE CHALLENGE POSED BY CLIMATE CHANGE}

Over the past decade, there has been growing awareness that climate change may significantly alter ecological functioning across the desert Southwest, including sites like LCNCA. Numerous models robustly predict that over the coming century this region will become increasingly warm and dry, with winter-time precipitation falling dramatically and temperatures rising $3-5^{\circ} \mathrm{C}$ (Christensen et al. 2007, Diffenbaugh et al. 2008, Seager and Vecchi 2010). Temperatures across the desert Southwest have already risen by more than $1{ }^{\circ} \mathrm{C}$ over the past several decades, and much of the region has been mired in a decade-long drought, perhaps indicative of future precipitation regimes (Seager et al. 2007).

This anticipated shift in temperature-precipitation regimes has been coupled with a number of more rapid changes, including increasing development, intensifying water-use, and the spread of non-native species. Population growth in the American Southwest has been staggering, rising from 3 million in 1900 to over 50 million people in 2000 (MacDonald 2010). Water usage from 1950 to 2000 has nearly doubled (Koniecski and Heilman 2004), and hydrologic changes have 
Table 1. Numerous changes observed in the Sonoita Valley are categorized by the amount of control local managers and stakeholders have over these changes. As control of their causes and consequences decreases, nested management objectives and scenario planning become increasingly important. Changes marked with $\dagger$ represent changes that stakeholders have indicated should be considered components of any scenario planning exercise.

\begin{tabular}{lll}
\hline \hline & \multicolumn{1}{c}{ Controllability } \\
Moderate & Low & None \\
\hline Grazing intensity, rotation & Border infrastructure & Climate change $\dagger$ \\
Implementation of land agency policy & Land agency resources/policy $\dagger$ & Interannual climate variability \\
Recreation & Housing development & Population growth \\
Habitat fragmentation & Local economic activity & Regional/national economic activity \\
Invasive Species (bullfrogs) & Invasive species (Lehmann's Lovegrass) & National/international policy \\
Restoration Projects & Alternative energy infrastructure & \\
Water quality & Water quantity & \\
& Sale of State Trust Land & \\
\hline
\end{tabular}

been profound (Barnett et al. 2008). The combination of these changes with a changing climate will tax the already stressed ecosystems across the Southwest (Serrat-Capdevila et al. 2007, Marshall et al. 2010, Powell 2010).

As a result, the desert Southwest is becoming a focal point for discussions on preparing for and responding to climate change in a way that reduces impacts to natural and human communities. The exact trajectory that climate change will follow is unknown even on the global scale, and on a regional or local scale is still poorly understood. How species and resources respond to changing climatic conditions is an expanding area of research (Parmesan 2006, Allen et al. 2010, McDowell et al. 2011). Despite many recent discoveries, however, surprises abound (Williams and Jackson 2007), and it remains difficult for managers to apply this growing body of knowledge at individual sites. How societies will respond to a changing climate is also unknown, and any response is likely to significantly impact ecological systems. Other threats, such as urban sprawl, energy development, and mineral extraction, often occur with limited long-term planning considerations; these threats are tied to fluctuations in the national economy, making predictions on the local-scale difficult. Land management agencies face increasing political and financial uncertainty because of political gridlock. Preparing for and responding to climate change will therefore be complicated by vast uncertainties (Peterson et al. 2003, Millar et al. 2007, Julius and West 2008, Baron et al. 2009, Lawler et al. 2010). Such uncertainties will make it difficult for managers to succeed at sustaining, in perpetuity, the benefits of public lands. Others have noted the constraints these externalities place upon collaborative institutions that are often geared to respond to issues that are largely internal to an ecosystem (York and Schoon 2011).

Increased awareness among LCNCA stakeholders and managers about the potential impacts of climate change has grown out of conversations with climate experts and modelers, communications with other public land managers, resource scientists, and conservation organizations, monitoring established by the CAM process, and direct observation of changes within the Sonoita Valley and the surrounding region. The increased awareness about potential climate change impacts, coupled with other unpredictable and largely uncontrollable changes occurring in the region has resulted in the acknowledgement at LCNCA of the need to consider how to anticipate and respond to these changes (Table 1). Some decisions are likely to be exceedingly difficult (Craig 2010), not only because they will be contentious, but also because the impact of these changes, and how these changes will merge and affect each other, is highly uncertain.

Many authors have advocated adaptive management and collaboration as key tools for providing the flexibility, learning, and public support needed to prepare for and respond to climate change and other rapid changes (Baron et al. 2009, Heller and Zavaletta 2009, Lawler et al. 2010). The experience with CAM at LCNCA gives the site a head start in addressing these emerging challenges. Focused ecological monitoring and adaptive response loops enable participants to observe changes as they occur and provide a mechanism for discussing implications of these changes on management decisions. Stakeholder involvement, broad expertise, and a tradition of shared learning enhance the group's ability to contemplate future changes. Having cultivated shared goals, trusting relationships, and developed essential problem-solving skills, the CAM process provides a foundation for making the difficult and contentious management decisions that uncertain changes are likely to require.

\section{BUILDING ON CAM}

Despite the evident benefits of CAM elements outlined above, stakeholders recognize that additional tools may be required to address these emerging challenges. Further, making adjustments to existing activities may not be enough to buffer ecosystems and the services and benefits they provide to 
human communities from the effects of these changes. For these reasons, LCNCA stakeholders engaged experts at the 2010 Collaborative Adaptive Management Network (CAMNet) conference to help think through both the benefits and limitations of CAM processes in preparing for and responding to rapid and uncontrollable change.

CAMNet discussions, and a subsequent report for LCNCA about how to address climate change uncertainty in collaborative decision-cycles (J. Caves 2010 Scenario Planning at Las Cienegas: Decision Support Tools and Futures Planning, unpublished manuscript), generated two main ideas that participants have continued to explore at LCNCA since 2010: re-evaluating management objectives through a climate change lens, and using scenario planning tools to explore additional types of uncertainty created by these rapid changes. The report's recommendations and the ideas generated at CAMNet continue to be discussed at biological planning meetings. These discussions raised questions about whether existing objectives will be adequate, achievable, or even desirable in the future. However, few managers or stakeholders were ready to simply abandon existing objectives. Participants wanted tools that would help them rigorously and transparently explore which objectives might be especially important in the future, and which might only promote inflexible attempts to recapture a bygone past. Similarly, the observation that so many of these changes appear to be beyond local manager and stakeholders' control has prompted ongoing discussions about the inherent limitations of conventional adaptive management. Discussions of scenario planning as a tool for addressing how such uncontrollable drivers may interact to impact the landscape have resonated with participants, and they have begun blending these tools into the CAM approach.

\section{Nested objectives: from core to conditional}

Measuring progress toward specific, ecologically-based targets for desired resource conditions has been a cornerstone of LCNCA CAM; yet, this creates a surprising conflict when faced with a changing climate. The LCNCA RMP objectives were derived from shared goals using best available science that captured collective understanding of the functions, processes, and compositions of current and historical ecosystems. However, with changes in temperature and precipitation already being observed, ecosystem processes and composition cannot be assumed to remain stationary (Milly et al. 2008), nor are they likely to only change within historic range of variation (Williams and Jackson 2007). Given the uncertainty of future changes, the existing specific, numerically driven RMP objectives may become obsolete despite the best efforts of BLM and stakeholders. Others have recognized this shortcoming; an analysis of management plans across BLM special management units rated LCNCA low on being prepared to deal with climate change, precisely because the RMP has such specific resource objectives (Koopman
2010). Despite the drawbacks of managing toward objectives that specify ecosystem parameters based upon historical conditions, discarding these measurable objectives overall would leave the LCNCA CAM process without essential benchmarks.

Evaluating existing RMP objectives from a climate change perspective may help resolve this dilemma. Under a shifting climate, some RMP objectives may be more achievable than others, and some may contribute more to overall shared goals of healthy watersheds and communities in the future. To accommodate both specific, historically based objectives and objectives aimed at maintaining ecosystem resilience into the future, RMP objectives can be organized in a nested structure (Fig. 5): core objectives that emphasize long-term watershed functioning, for example, would be surrounded by specific objectives based upon historical indicators of watershed health components such as erosion thresholds, and subsequently, by desired conditions for individual species or assemblages. In this example, the outer objectives are seen as being more dependent on assumptions of stationarity and therefore less controllable, while the core objectives represent those components necessary to maintain ecological resilience in the watershed. This nested structure suggests that as climate shifts and ecosystems respond, some conditional objectives could be discarded and others retained, while the core objectives are intended to be achieved under any future scenario.

The process of employing this nested objective structure, and any subsequent decision to discard conditional objectives, will need to continue the LCNCA tradition of stakeholder engagement. Such an effort may be contentious, but encouraging open participation should continue to be viewed as an opportunity to educate one another about the relationships among objectives, to generate objectives that encompass an array of environmental and social factors, and to improve support for whatever core objectives are ultimately chosen. The scenario planning approach described below could guide such open discussions of what constitutes core objectives, and could add rigor to evaluations of conditional objectives.

\section{Incorporating scenario planning}

Scenario planning is designed to consider a variety of possible and plausible futures rather than decide upon a particular, accurate future prediction (Mahmoud et al. 2009). Using these various scenarios, stakeholders can determine which decisions, objectives, and monitoring targets are most relevant under a range of future conditions. Further, scenario planning can specifically address surprises and unanticipated threats by providing a structure to make decisions based upon these scenarios (Peterson et al. 2003, see their Fig. 1). As a result, climate change can be explicitly considered with other, unrelated impacts, such as mineral extraction, recreation, and development to understand linkages between these changes and produce a web of future trajectories. 
Fig. 5. An example of nested resource management objectives. The concept of nested objectives is a theoretical innovation designed to reconcile adaptive management's needs for measureable objectives, which are often formulated based upon past experience, with the threat that climate change could move this site into an ecological state with no historical analog. At the center of this diagram are core objectives that are crucial to multiple societal goals and that are intended to be met despite changes in climate or other conditions. Moving outward from the core, objectives become increasingly specific and the ability to meet them becomes increasingly dependent on assumptions of stationarity. Therefore, outer objectives may be outside of managers' control and might be considered conditional, to be modified as they become unachievable or conflict with other objectives. Within each circle are examples of shared goals and resource management objectives.

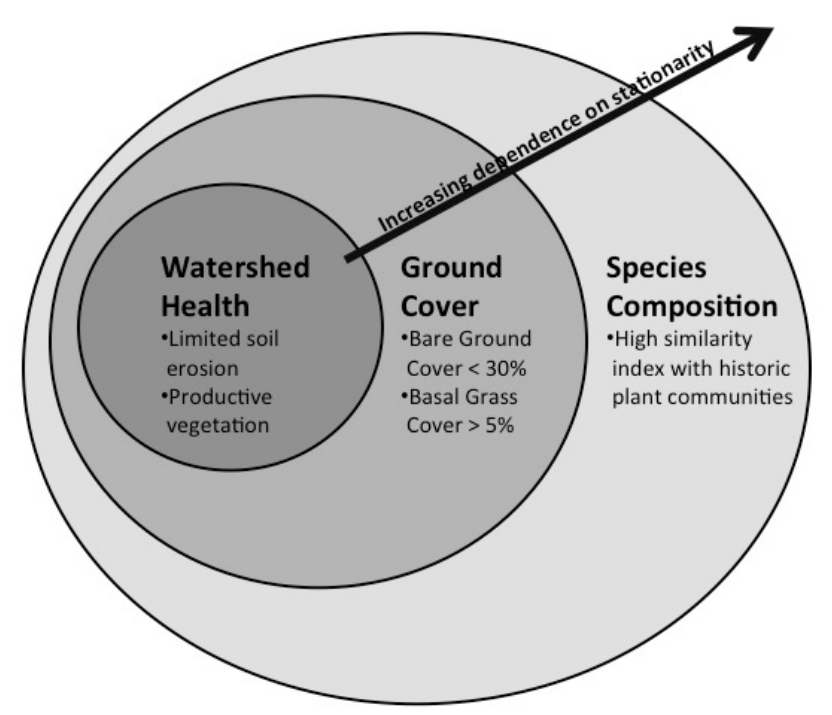

To investigate options for integrating scenario planning into the LCNCA CAM process, the group invited scenario planning experts to community science forums. Based on these discussions, the group outlined three steps for effectively merging scenario planning and CAM.

- Construct scenarios to characterize possible futures and identify sources of uncertainty;

- Use the scenarios to review objectives and to identify both robust and contingent actions;

- Revise ecological monitoring to better cover the sources of uncertainty.

These steps, which have only recently been initiated at LCNCA, will require continued active collaboration among stakeholders and public land agencies. Indeed, scenario planning augments this collaboration, by providing a structure with which to collectively learn about, discuss, and act upon the highly uncertain and uncontrollable changes already facing the area.

\section{Construct scenarios}

An ongoing challenge in CAM has been a coherent method to explore the uncertain, uncontrollable factors that may impact the landscape (Williams et al. 2009; Cienega Watershed Partnership, State of the Watershed, unpublished report 2010; Table 1). Scenario construction creates a framework to more explicitly explore uncertainties and how they impact the watershed by developing models that simulate how an ecosystem responds to these uncertainties (Mahmoud et al. 2009). Such models can greatly aid in understanding which changes occurring in the Cienega watershed may have a greater impact on LCNCA. For example, future uses of State Trust Lands that are adjacent to much of LCNCA, and over which BLM and stakeholders have little control, represent a major uncertainty. To capture this and other externalities, stakeholders have asked that scenario construction include agency budgets and societal investment as major components, as has been done with the National Park Service (Weeks et al. 2011). Constructing scenarios that incorporate these uncertainties with shifting temperature and precipitation regimes will document how these potential changes interact to produce varying ecosystem responses.

These models could improve the decision-making process at LCNCA in a number of important ways and help the LCNCA CAM process survive potentially large social and ecological changes. First, models could enhance shared understanding of how changes in and to the region may interact to impact LCNCA. Second, models can be used to explore the critical, yet potentially contentious decisions that may have to be made under different scenarios. Third, models may help prioritize actions and monitoring, both spatially and temporally, to maximize efficient use of resources. Finally, models provide another mechanism to fully capture the range of knowledge various stakeholders possess about the LCNCA system.

\section{Identifying robust actions}

A direct outcome of scenario planning is the identification of management actions that, ideally, will help meet the core objectives of improving ecological resiliency regardless of future socioeconomic or environmental conditions. Given the increasingly constrained budgets of land management agencies, these "robust" actions gain additional importance, allowing LCNCA to maximize ecological benefits with a minimum of wasted effort (Lempert and Schlesinger 2000). Identifying robust actions as early as possible allows participants to more quickly respond to rapid change and builds capacity among participants to continue using scenario planning tools when needed. As important, scenario planning 
should identify actions already occurring or planned to occur that only meet core objectives under certain scenarios and, therefore, are considered contingent rather than robust. Additionally, these scenario planning exercises could be used to evaluate the utility of the nested objective structure and inform when conditional objectives might be dropped or modified.

LCNCA has already begun focusing on some robust actions based upon knowledge generated through the CAM process: (1) building resilience into floodplains through restoration and enhancement activities, including restoring riparian sacaton grasslands and reducing erosion in arroyos; and (2) working with partners to continue protecting landscape connectivity, particularly along elevational and latitudinal gradients through purchases of land and easements of target areas that protect key water resources. Protection efforts by BLM and partners have already secured east-west connectivity between "sky island" mountain ranges (Pima County Board of Supervisors 2011). Some landscape connectivity initiatives have made use of the unique and forward-thinking provision in the LCNCA Establishment Act that created the Sonoita Valley Acquisition Planning District. This provision provides for future acquisitions of lands or easements by BLM within the District and for their addition to LCNCA without further legislative action. Additional investments are gradually securing northsouth connectivity between two more ranges. These connected lands include terrain managed by BLM, U.S. Forest Service, National Park Service, Pima County, Fort Huachuca, Arizona State Parks Department, TNC, and private landowners. These actions improve ecological resilience by simultaneously addressing many of the changes and challenges (see Table 1) facing the Cienega Watershed.

\section{Prioritizing ecological monitoring efforts}

Although evaluations described above are improving how LCNCA monitoring tracks ecosystem change relative to existing objectives and previously recognized thresholds, these reviews have not yet addressed possible novel ecosystem dynamics or shifting thresholds. Scenario planning may identify critical aspects of the ecosystem that will be sensitive to threshold-level changes that monitoring could examine to determine if the system is moving into realms described by one scenario or another. This evidence could, in turn, prompt the group to shift management direction as they deem some objectives no longer achievable or appropriate, moving from managing for resilience to managing for change (Craig 2010, Lawler et al. 2010).

Some monitoring protocols are already being modified to better track climate-related parameters. For example, the LCNCA recently installed an array of more accurate rain gauges to help understand drought impacts across the landscape and to document the magnitude of storm events that may be increasing in intensity and variability (Christensen et al. 2007). Stakeholders are working to integrate existing climate stations into monitoring efforts and determine what additional information needs to be collected across the site. TNC and BLM staff have also begun monitoring groundwater changes to detect impacts of drought and human activities, as well as improve modeling of the basin's dynamic water resources.

\section{THEORETICAL LESSONS}

In addition to highlighting key practical lessons for implementing and modifying CAM, the experiences at Las Cienegas provide insight into a theoretical framework for addressing the full range of complexity that faces natural resource systems. We suggest that such complexity can be broken into ecological, social, and temporal elements (Fig. 6), and illustrate how this trio of complementary tools, i.e., collaboration, adaptive management, and scenario planning, are each suited to addressing particular aspects of this complexity.

Fig. 6. Three types of complexity face land managers: temporal, ecological, and social. Each of these complexities can be addressed using complementary tools: adaptive management, collaboration, and scenario planning. Adaptive management is well suited to responding to slowmoderate changes and to using the scientific process to address ecological questions. Collaboration addresses ecological complexity by increasing the breadth of knowledge available to land managers and stakeholders, while also improving outcomes where there are local and/or internal conflicts. Scenario planning provides a structure to aid land managers and stakeholders in anticipating more rapid, external, or large-scale changes that may impact the natural-resource system.

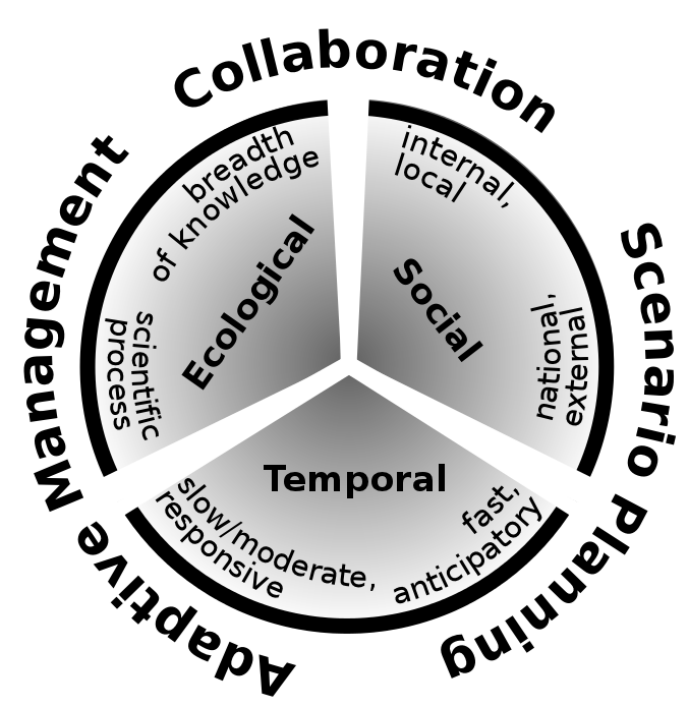


Adaptive management is designed to harness the scientific process to understand and work with ecological complexity. Its ability to address temporal complexity in an ecosystem, i. e., unpredictable changes through time, is largely responsive because participants monitor results and modify subsequent actions. Collaboration brings in the ecological knowledge of stakeholders to augment land managers' expertise. Collaboration also folds societal dynamics, including economics, into decision making; as stakeholders address local and internal conflicts, their participation can yield increased support for contentious decisions. Scenario planning fills a critical gap by providing a structure with which to understand and anticipate externalities that are beyond the control of land managers or stakeholders. Such externalities include societal issues at the state and national levels, including changes in policy or budgets, as well as rapid global and regional ecological externalities such as climate shifts. In this sense, scenario planning allows participants to anticipate and plan for the effects of such externalities rather than simply respond to external forcings as they occur.

In applying this combination of tools, we have also proposed an innovative structure to "nest" descriptions of desired resource conditions in a way that reconciles adaptive management's needs for measurable objectives, which are often based on past conditions, with the recognition that climatic changes can create novel ecosystems. Allowing for flexibility in objectives creates a need for additional rigor to ensure that the objectives being used continue to track and promote progress toward agreed-upon goals. Scenario planning can provide that rigor by helping participants explicitly identify the conditions under which each set of objectives would continue to support ecosystem resilience versus where they may hinder responses to inevitable change.

Finally, we return to the concept of using the four core elements to implement CAM. Our experience at Las Cienegas has demonstrated that these elements can create a structure and philosophy that emphasize continued improvement of the CAM process. These observations suggest that using these core elements will be as valuable for designing and applying modifications to CAM as for developing such inclusive, responsive processes to begin with.

\section{CONCLUSIONS}

Years of experience at this site confirm the value and relevance of collaborative adaptive management approaches. The four core elements that have emerged from experience have served the site well, allowing for flexible management actions that strive to achieve shared goals, ensuring that monitoring informs actions, creating mechanisms for collaboration, and encouraging continued shared learning. As a result, managers and stakeholders have achieved several important milestones, including: the adoption of a resource management plan with broad community support; a suite of partners that are invested in implementing the plan; a regular and effective ecological monitoring program that tracks changes on the ground; and the ability to work collaboratively to adapt management decisions to suit changing conditions. Managers and stakeholders at other BLM sites such as the Agua Fria National Monument have noted the benefits of this approach, and are looking to our CAM process as an example that they can adapt and use at their own sites.

This foundation will be crucial for adapting to global climate change, the effects of which are already being seen across the desert Southwest. Managers and stakeholders in this watershed have long attempted to work across multiple jurisdictions within the broader landscape, addressing emerging stressors by emphasizing landscape connectivity and resilience. More recently, BLM and stakeholders at LCNCA have begun to enhance CAM by incorporating flexibility into the RMP objectives through nesting objectives and adding scenario planning. These modifications will explicitly prepare managers and stakeholders to understand how multiple external drivers may interact with ecosystem responses, and identify robust actions and monitoring efforts needed to respond to and detect the rapid and uncontrollable changes facing the Cienega Watershed.

The evolution of CAM at this site parallels a growing recognition nationwide that public lands can no longer be managed as isolated parcels; rather, protection of these critical lands and resources must address ecological, social, and temporal complexity that often spans land boundaries and traditional planning horizons. Public lands across the country face similar pressures that will require new planning tools to sustain the benefits of these lands. The LCNCA experience demonstrates that collaborative adaptive management can prepare managers and stakeholders to face these challenges, but that additional tools, currently being implemented at this site, may be necessary to fully address the range of complexity and change faced by public lands. Fortunately, these tools are all broadly applicable. Such an approach promises to help managers and stakeholders effectively navigate the complexity and change that threatens to overwhelm even the best efforts to sustain public land resources.

Responses to this article can be read online at: http://www.ecologyandsociety.org/issues/responses. $\mathrm{php} / 5749$

\section{Acknowledgments:}

This project is an outgrowth of 20 years of hand-wringing, stumbling, celebration, and joy. On behalf of the many people who have a vested interest in the health of this landscape, the 
authors are grateful for all the camaraderie and hard work of the participants of SVPP and the Biological Planning Team, without whom this work would not have been possible. The authors wish to thank Carolyn Enquist, Greg Garfin, Dave Gori, Holly Hartmann, Rob Marshall, Maggie McCaffrey, Brian Powell, Marcos Robles, Ed Smith, Christine Turner, and Jeff Williamson for ongoing discussions about the intersection of climate adaptation, adaptive management, and scenario planning. We also thank Steve Cohn and Michael Schoon for providing thoughtful comments that significantly improved this manuscript. Thanks is also due to the U.S. Institute for Environmental Conflict Resolution for supporting JKC while working with the BLM and stakeholders on a paper about integrating climate change uncertainty into decision-cycles. Funding for this paper came from The Nature Conservancy, the Bureau of Land Management, and a NSF Graduate Research Fellowship to JKC.

\section{LITERATURE CITED}

Allen, C. D., A. K. Macalady, H. Chenchouni, D. Bachelet, N. McDowell, M. Vennetier, T. Kitzberger, A. Rigling, D. D. Breshears, E. H. T. Hogg, P. Gonzalez, R. Fensham, Z. Zhang, J. Castro, N. Demidova, J.-H. Lim, G. Allard, S. W. Running, A. Semerci, and N. Cobb. 2010. A global overview of drought and heat-induced tree mortality reveals emerging climate change risks for forests. Forest Ecology and Management 259 (4):660-684.

Armitage, D. R., F. Berkes, and N. C. Doubleday. 2007. Introduction: moving beyond co-management. Pages 1-18 in D. Armitage, F. Berkes, and N. C. Doubleday, editors. Adaptive co-management: collaboration, learning, and multilevel governance. University of British Columbia Press, Vancouver, British Columbia, Canada.

Armitage, D. R., R. Plummer, F. Berkes, R. I. Arthur, A. T. Charles, I. J. Davidson-Hunt, A. P. Diduck, N. C. Doubleday, D. S. Johnson, M. Marschke, P. McConney, E. W. Pinkerton, and E. K. Wollenberg. 2009. Adaptive co-management for social-ecological complexity. Frontiers in Ecology and the Environment 7:95-102. http://dx.doi.org/10.1890/070089

Barnett, T. P., D. W. Pierce, H. G. Hidalgo, C. Bonfils, B. D. Santer, T. Das, G. Bala, A. W. Wood, T. Nozawa, A. A. Mirin, D. R. Cayan, and M. D. Dettinger. 2008. Human-induced changes in the hydrology of the western United States. Science 319(5866):1080-1083. http://dx.doi.org/10.1126/science.1152538

Baron, J. S., L. Gunderson, C. D. Allen, E. Fleishman, D. McKenzie, L. Meyerson, J. Oropeza, and N. Stephenson. 2009. Options for national parks and reserves for adapting to climate change. Environmental Management 44:1033-1042. http://dx.doi.org/10.1007/s00267-009-9296-6

Beier, P., D. Majka, and T. Bayless. 2006. Arizona missing linkages: Rincon - Santa Rita - Whetstone Linkage Design.
Report to Arizona Game and Fish Department. School of Forestry, Northern Arizona University, Flagstaff, Arizona, USA. [online] URL: http://corridordesign.org/dl/linkages/ reports/Rincon-SantaRita-Whetstone_LinkageDesign.pdf

Bestelmeyer, B. T. 2006. Threshold concepts and their use in rangeland management and restoration: the good, the bad, and the insidious. Restoration Ecology 14(3):325-329. http://dx. doi.org/10.1111/j.1526-100X.2006.00140.X

Bestelmeyer, B. T., A. J. Tugel, G. L. Peacock, D. G. Robinett, P. L. Shaver, J. R. Brown, J. E. Herrick, H. Sanchez, and K. M. Havstad. 2009. State-and-transition models for heterogeneous landscapes: a strategy for development and application. Rangeland Ecology \& Management 62(1):1-15. http://dx.doi.org/10.2111/08-146

Bodner, G., L. Kennedy, K. Simms, and J. Williamson. 2012. Science on the Sonoita Plain. Page 24 in Merging Science and Management in a Rapidly Changing World. Biodiversity and Management of the Madrean Archipelago III and 7th Conference on Research and Resource Management in the Southwestern Deserts. U.S. Forest Service Rocky Mountain Research Station, Fort Collins, Colorado, USA.

Bota, L. 1997. Modeling groundwater flow and surfacel groundwater interaction for upper Cienega Creek basin. Thesis. University of Arizona, Tucson, Arizona, USA.

Bureau of Land Management. 2003. Approved Las Cienegas resource management plan and record of decision. U.S. Department of the Interior, Bureau of Land Management, Tucson Field Office, Arizona, USA. [online] URL: http:// www.blm.gov/pgdata/etc/medialib/blm/az/pdfs/nepa/library/ resource management.Par.73866.File.dat/LCROD-WEB.pdf

Bureau of Land Management. 2009. Bureau of Land Management National Natural Resources Policy for Collaborative Stakeholder Engagement and Appropriate Dispute Resolution: what BLM, communities, and the public need to know for preventing conflict and resolving disputes involving public lands and resources. U.S. Department of the Interior, Bureau of Land Management, Washington, D.C., USA. [online] URL: http://www.blm.gov/pgdata/etc/medialib/ blm/wo/Planning and Renewable Resources/adr conflict prevention. Par.44228.File.dat/ADR.pdf

Childs, C., A. M. York, D. White, M. L. Schoon, and G. S. Bodner. 2013. Navigating a murky adaptive comanagement governance network: Agua Fria Watershed, Arizona, USA. Ecology and Society 18(4): in press.

Christensen, N. L., A. M. Bartuska, J. H. Brown, S. Carpenter, C. D'Antonio, R. Francis, J. F. Franklin, J. A. MacMahon, R. F. Noss, D. J. Parsons, C. H. Peterson, M. G. Turner, and R. G. Woodmansee. 1996. The report of the Ecological Society of America Committee on the Scientific Basis for Ecosystem 
Management. Ecological Applications 6:665-691. http://dx. doi.org/10.2307/2269460

Christensen, J. H., B. Hewitson, A. Busuioc, A. Chen, X. Gao, I. Held, R. Jones, R. K. Kolli, W.-T. Kwon, R. Laprise, V. Magaña Rueda, L. Mearns, C. G. Menéndez, J. Räisänen, A. Rinke, A. Sarr, and P. Whetton. 2007. Regional climate projections. Chapter 11 in S. Solomon, D. Qin, M. Manning, Z. Chen, M. Marquis, K. B. Averyt, M. Tignor, and H. L. Miller, editors. Climate change 2007: the physical science basis. Contribution of Working Group I to the Fourth Assessment Report of the Intergovernmental Panel on Climate Change. Cambridge University Press, New York, New York, USA.

Craig, R. K. 2010. "Stationarity is dead"-long live transformation: five principles for climate change adaptation law. Harvard Environmental Law Review 573(2008):9-74.

Diffenbaugh, N. S., F. Giorgi, and J. S. Pal. 2008. Climate change hotspots in the United States. Geophysical Research Letters 35(16):1-5. http://dx.doi.org/10.1029/2008GL035075

Dowell, G. P. 1978. History of the Empire Ranch. Thesis. University of Arizona, Tucson, Arizona, USA.

Eddy, F. W., and M. E. Cooley. 1983. Cultural and environmental history of Cienega Valley, southeastern Arizona. University of Arizona Press, Tucson, Arizona, USA.

Folke, C., T. Hahn, P. Olsson, and J. Norberg. 2005. Adaptive governance of social-ecological systems. Annual Review of Environment and Resources 30:441-473. http://dx.doi. org/10.1146/annurev.energy.30.050504.144511

Fonseca, J. 2008. Aquifer monitoring for groundwaterdependent ecosystems, Pima County, Arizona. Report to the Pima County Board of Supervisors. Pima County, Tucson, Arizona, USA. [online] URL: http://www.pima.gov/cmo/ sdcp/Monitoring/PDF/Fonseca_2008_Groundwater_Monitoring. pdf

Gori, D., and H. Schussman. 2005. State of the Las Cienegas National Conservation Area. Part I. Condition and trend of the desert grassland and watershed. The Nature Conservancy of Arizona, Phoenix, Arizona, USA. [online] URL: http:// azconservation.org/dl/TNCAZ_LasCienegas_StateOf_Part_1. pdf

Gori, D., K. Simms, M. Donaldson, G. S. Bodner, and H. Schussman. 2010. Adaptive management of the grasslandwatershed at Las Cienegas National Conservation Area: the role of monitoring, rancher engagement, and multistakeholder advisory teams. Pages 131-142 in W. Halverson, C. Shwalbe, and C. van Riper III, editors. Southwestern desert resources. University of Arizona Press, Tucson, Arizona, USA.
Groffman, P. M., J. S. Baron, T. Blett, A. J. Gold, I. Goodman, L. H. Gunderson, B. M. Levinson, M. A. Palmer, H. W. Paerl, G. D. Peterson, N. LeRoy Poff, D. W. Rejeski, J. F. Reynolds, M. G. Turner, K. C. Weathers, and J. Wiens. 2006. Ecological thresholds: the key to successful environmental management or an important concept with no practical application? Ecosystems 9(1):1-13. http://dx.doi.org/10.1007/s10021-003-0142$\underline{\mathrm{Z}}$

Grumbine, R. E. 1994. What is ecosystem management? Conservation Biology 8(1):27-38. http://dx.doi.org/10.1046/ j.1523-1739.1994.08010027.x

Gunderson, L. 1999. Resilience, flexibility and adaptive management - antidotes for spurious certitude? Conservation Ecology 3(1): 7. [online] URL: http://www.consecol.org/vol3/ iss $1 /$ art7/

Gunderson, L. H., and C. S. Holling. 2002. Panarchy: understanding transformations in human and natural systems. Island Press, Washington, D.C., USA.

Heller, N. E., and E. S. Zavaleta. 2009. Biodiversity management in the face of climate change: a review of 22 years of recommendations. Biological Conservation 142 (1):14-32. http://dx.doi.org/10.1016/j.biocon.2008.10.006

Holling, C. S., editor. 1978. Adaptive environmental assessment and management. Wiley, New York, New York, USA.

Hughes, K. 2010. National Landscape Conservation System FY 2010 annual manager's report: Las Cienegas National Conservation Area. Bureau of Land Management, U.S. Department of the Interior, Washington, D.C., USA. [online] URL: http://www.blm.gov/pgdata/etc/medialib/blm/az/pdfs/ nlcs.Par.80614.File.dat/Las-Cienegas-NCA-2010-Annual.pdf

Johnson, B. L. 1999. The role of adaptive management as an operational approach for resource management agencies. Conservation Ecology 3(2): 8. [online] URL: http://www. ecologyandsociety.org/vol3/iss2/art8/

Julius, S. H., and J. M. West, editors. 2008. Preliminary review of adaptation options for climate-sensitive ecosystems and resources. Final Report, Synthesis and Assessment Product 4.4. Report by the U.S. Climate Change Science Program and the Subcommittee on Global Change Research. U.S. Environmental Protection Agency, Washington, D.C., USA. [online] URL: http://www.climatescience.gov/Library/sap/ sap4-4/final-report/\#finalreport

Kaufmann, M. R., R. T. Graham, D. A. Boyce Jr., W. H. Moir, L. Perry, R. T. Reynolds, R. L. Bassett, P. Mehlhop, C. B. Edminster, W. M. Block, and P. S. Corn. 1994. An ecological basis for ecosystem management. General Technical Report RM 246. U.S. Department of Agriculture, Forest Service, 
Rocky Mountain Forest and Range Experiment Station, Fort Collins, Colorado, USA. [online] URL: http://library.eri.nau. edu/gsdl/collect/erilibra/import/KaufmannEtal.1994. AnEcologicalBasisForEcosystem.pdf

Keith, S. J. 1981. Stream channel recharge in the Tucson Basin and its implications for ground-water management. Dissertation. University of Arizona, Tucson, Arizona, USA.

Knapp, C. N., M. E. Fernandez-Gimenez, D. D. Briske, B. T. Bestelmeyer, and X. B. Wu. 2011a. An assessment of stateand-transition models: perceptions following two decades of development and implementation. Rangeland Ecology and Management 64(6):598-606. http://dx.doi.org/10.2111/REMD-10-00188.1

Knapp, C. N., M. Fernandez-Gimenez, E. Kachergis, and A. Rudeen. $2011 b$. Using participatory workshops to integrate state-and-transition models created with local knowledge and ecological data. Rangeland Ecology and Management 64 (2):158-170. http://dx.doi.org/10.2111/REM-D-10-00047.1

Knight, E. L. 1996. A water budget and land management recommendations for Upper Cienega Creek Basin. Dissertation. University of Arizona, Tucson, Arizona, USA.

Konieczki, A. D., and J. A. Heilman. 2004. Water-use trends in the desert Southwest-1950-2000. USGS Scientific Investigations Report 2004-5148, U.S. Geological Survey, Reston, Virginia, USA.

Koopman, M. E. 2010. Climate change preparation planning on national landscape conservation system lands: recommendations for direction and approach. National Center for Conservation Science and Policy, Ashland, Oregon, USA. [online] URL: http://www.geosinstitute.org/images/stories/ pdfs/climatechange_nlcs_smallfinal.pdf

Lawler, J. J., T. H. Tear, C. Pyke, M. R. Shaw, P. Gonzalez, P. Kareiva, L. Hansen, L. Hannah, K. Klausmeyer, A. Aldous, C. Bienz, and S. Pearsall. 2010. Resource management in a changing and uncertain climate. Frontiers in Ecology and the Environment 8(1):35-43. http://dx.doi.org/10.1890/070146

Lempert, R. J., and M. E. Schlesinger. 2000. Robust strategies for abating climate change. Climatic Change 45 (3-4):387-401. http://dx.doi.org/10.1023/A:1005698407365

MacDonald, G. M. 2010. Water, climate change, and sustainability in the southwest. Proceedings of the National Academy of Sciences of the United States of America 107 (50):21256-21262. http://dx. doi.org/10.1073/pnas.0909651107

Mahmoud, M., Y. Liu, H. Hartmann, S. Stewart, T. Wagener, D. Semmens, R. Stewart, H. Gupta, D. Dominguez, F. Dominguez, D. Hulse, R. Letcher, B. Rashleigh, C. Smith, R. Street, J. Ticehurst, M. Twery, H. van Delden, R. Waldick, D. White, and L. Winter. 2009. A formal framework for scenario development in support of environmental decision-making.
Environmental Modelling and Software 24(7):798-808. http:// dx.doi.org/10.1016/j.envsoft.2008.11.010

Majewski, T., S. O'Mack, E. J. Meane, M. A. Sterner, with contributions by M. Green and B. Vint. 2004. Adaptive reuse plan for the Empire Ranch headquarters. Prepared for Empire Ranch Foundation, Sonoita, Arizona. SRI Technical Report 03-64. Statistical Research, Inc., Tucson, Arizona, USA.

Marshall, R. M., M. D. Robles, D. R. Majka, and J. A. Haney. 2010. Sustainable water management in the southwestern United States: reality or rhetoric? PloS ONE 5(7):e11687. http://dx.doi.org/10.1371/journal.pone.0011687

McDowell, N. G., D. J. Beerling, D. D. Breshears, R. A. Fisher, K. F. Raffa, and M. Stitt. 2011. The interdependence of mechanisms underlying climate-driven vegetation mortality. Trends in Ecology \& Evolution 26(10):523-532. http://dx.doi. org/10.1016/j.tree.2011.06.003

Meridian Institute. 2010. CAMNet annual rendezvous: summary. Collaborative Adaptive Management Network, Tucson, Arizona, USA. [online] URL: http://www. adaptivemanagement.net/sites/default/files/2010\%20CAMNet\% 20Summary\%20for\%20posting.pdf

Millar, C. I., N. L. Stephenson, and S. L. Stephens. 2007. Climate change and forests of the future: managing in the face of uncertainty. Ecological Applications 17(8):2145-2151. http://dx.doi.org/10.1890/06-1715.1

Milly, P. C. D., J. Betancourt, M. Falkenmark, R. M. Hirsch, Z. W. Kundzewicz, D. P. Lettenmaier, and R. J. Stouffer. 2008. Stationarity is dead: whither water management? Science 319:573-574. http://dx.doi.org/10.1126/science.1151915

Moir, W. H., and W. M. Block. 2001. Adaptive management on public lands in the United States: commitment or rhetoric? Environmental Management 28(2):141-148. http://dx.doi. org/10.1007/s002670010213

National Park Service. 2012. About us. National Park Service, U.S. Department of the Interior, Washington, D.C., USA. [online] URL: http://www.nps.gov/aboutus/index.htm

Pahl-wostl, C., M. Craps, A. Dewulf, E. Mostert, D. Tabara, and T. Taillieu. 2007. Social learning and water resources management. Ecology and Society 12(2): 5. [online] URL: http://www.ecologyandsociety.org/vol12/iss2/art5/

Parmesan, C. 2006. Ecological and evolutionary responses to recent climate change. Annual Review of Ecology, Evolution, and Systematics 37:637-669. http://dx.doi.org/10.1146/ annurev.ecolsys.37.091305.110100

Peterson, G. D., G. S. Cumming, and S. R. Carpenter. 2003. Scenario planning: a tool for conservation in an uncertain world. Conservation Biology 17(2):358-366. http://dx.doi. org/10.1046/j.1523-1739.2003.01491.x 
Pima Association of Governments. 2000. Sonoran Desert Conservation Plan: GIS coverage of perennial and intermittent streams, and shallow groundwater. Pima Association of Governments, Tucson, Arizona, USA. [online] URL: http://rfcd.pima.gov/reports/pdfs/pima streams.pdf

Pima County Board of Supervisors. 1999. Water resources and the Sonoran Desert Conservation Plan: a discussion paper on the regional policy necessary to achieve meaningful riparian restoration. Pima County, Tucson, Arizona, USA. [online] URL: http://www.pima.gov/cmo/sdcp/reports/d7/001WAT. PDF.

Pima County Board of Supervisors. 2011. Protecting our land, water and heritage: Pima County's voter-supported conservation efforts. Report produced for the Sonoran Desert Conservation Plan. Pima County, Tucson, Arizona, USA. [online] URL: http://www.pima.gov/cmo/admin/Reports/ $\underline{\text { ConservationReport/ }}$

Plummer, R. 2009. The adaptive co-management process: an initial synthesis of representative models and influential variables. Ecology and Society 14(2): 24. [online] URL: http:// www.ecologyandsociety.org/vol14/iss2/art24/

Polasky, S., S. R. Carpenter, C. Folke, and B. Keeler. 2011. Decision-making under great uncertainty: environmental management in an era of global change. Trends in Ecology \& Evolution 26(8):398-404. http://dx.doi.org/10.1016/j.tree.2011.04.007

Pomeroy, R. 2007. Conditions for successful fisheries and coastal resources co-management: lessons learned in Asia, Africa, and the wider Caribbean. Pages 173-187 in D. Armitage, F. Berkes, and N. C. Doubleday, editors. Adaptive co-management: collaboration, learning, and multi-level governance. University of British Columbia Press, Vancouver, British Columbia, Canada.

Powell, B. F. 2010. Climate change and natural resources in Pima County: anticipated impacts and management challenges. Pima County, Tucson, Arizona, USA. [online] URL: http://www.pima.gov/cmo/sdcp/reports/d52/Ecological Impacts. pdf

Seager, R., M. Ting, I. Held, Y. Kushnir, J. Lu, G. Vecchi, H. Huang, N. Harnik, A. Leetmaa, N. Lau, C. Li, J. Velez, and N. Naik. 2007. Model projections of an imminent transition to a more arid climate in southwestern North America. Science 316:1181-1184. http://dx.doi.org/10.1126/science.1139601

Seager, R., and G. A. Vecchi. 2010. Greenhouse warming and the 21 st century hydroclimate of southwestern North America. Proceedings of the National Academy of Sciences of the United States of America 107(50):21277-21282. http://dx.doi. org/10.1073/pnas.0910856107
Serrat-Capdevila, A., A. Browning-Aiken, K. Lansey, T. Finan, and J. B. Valdés. 2009. Increasing social-ecological resilience by placing science at the decision table: the role of the San Pedro Basin (Arizona) decision-support system model. Ecology and Society 14(1): 37. [online] URL: http://www. ecologyandsociety.org/vol14/iss1/art37/

Serrat-Capdevila, A., J. B. Valdés, K. González-Pérez, K. Baird, L. J. Mata, and T. Maddock III. 2007. Modeling climate change impacts - and uncertainty - on the hydrology of a riparian system: the San Pedro basin (Arizona/Sonora). Journal of Hydrology 347(1-2):48-66. http://dx.doi. org/10.1016/j.jhydrol.2007.08.028

Shindler, B., and K. Aldred Cheek. 1999. Integrating citizens in adaptive management: a propositional analysis. Conservation Ecology 3(1): 9. [online] URL: http://www. consecol.org/vol3/iss1/art9/

Simms, K., G. Drennen, B. Cooper, G. S. Bodner, and D. Gori. 2006. Report on the biological planning process for livestock management at Las Cienegas NCA. The Nature Conservancy, Tucson, Arizona, USA. [online] URL: http://azconservation. org/dl/TNCAZ LasCienegas Biological Planning Process 2005. pdf

Stankey, G. H., B. T. Bormann, C. Ryan, B. Shindler, V. Sturtevant, R. N. Clark, and C. Philpot. 2003. Adaptive management and the northwest forest plan: rhetoric and reality. Journal of Forestry 101(1):40-46.

Swanson, E. H. 1951. An archaeological survey of the Empire Valley, Arizona. Thesis. University of Arizona, Tucson, Arizona, USA.

Szaro, R. C., W. T. Sexton, and C. R. Malone. 1998. The emergence of ecosystem management as a tool for meeting people's needs and sustaining ecosystems. Landscape and Urban Planning 40(1-3):1-7. http://dx.doi.org/10.1016/ S0169-2046(97)00093-5

Tiller, R. L., M. Hughes, and G. S. Bodner. 2012. Sacaton riparian grasslands: mapping distribution and ecological condition using state-and-transition models in Upper Cienega Creek Watershed. The Nature Conservancy, Tucson, Arizona, USA. [online] URL: http://azconservation.org/dl/

Sacaton_Grasslands_finalreport_mod10302012.pdf

U.S. Government. 2004. Executive Order 13,352. Federal Register 69(167). Government Printing Office, Washington, D.C., USA.

U.S. Senate. 2000. Public Law 106-538. An Act to establish the Las Cienegas National Conservation Area in the State of Arizona. U.S. Senate, Washington, D.C., USA. [online] URL: http://www.blm.gov/pgdata/etc/medialib/blm/az/images/cuenegas. Par.14910.File.dat/legislation_PL.pdf 
U.S. Senate. 2009a. Public Law 111-88. Interior Department and further continuing appropriations, Fiscal Year 2010. U. S. Senate, Washington, D.C., USA. [online] URL: http:// www.gpo.gov/fdsys/pkg/PLAW-111publ88/pdf/PLAW-111publ88. pdf

U.S. Senate. 2009b. Public Law 111-11. To designate certain land as components of the National Wilderness Preservation System, to authorize certain programs and activities in the Department of the Interior and the Department of Agriculture, and for other purposes. U.S. Senate, Washington, D.C., USA. [online] URL: http://www.gpo.gov/fdsys/pkg/PLAW-111publ11/ pdf/PLAW-111publ11.pdf

Walters, C. J. 1997. Challenges in adaptive management of riparian and coastal ecosystems. Conservation Ecology 1(2): 1. [online] URL: http://www.consecol.org/vol1/iss2/art1/

Walters, C. J., and C. S. Holling. 1990. Large-scale management experiments and learning by doing. Ecology 71:2060-2068. http://dx.doi.org/10.2307/1938620

Weeks, D., P. Malone, and L. Welling. 2011. Climate change scenario planning: a tool for managing parks into uncertain futures. ParkScience 28(1):26-33. [online] URL: http://www. nature.nps.gov/ParkScience/index.cfm?ArticleID $=475$

Williams, B. K., R. C. Szaro, and C. D. Shapiro. 2009. Adaptive management: the U.S. Department of the Interior technical guide. Adaptive Management Working Group, U.S. Department of the Interior, Washington, D.C., USA.

Williams, J. W., and S. T. Jackson. 2007. Novel climates, noanalog communities, and ecological surprises. Frontiers in Ecology and the Environment 5:475-482. http://dx.doi. org/10.1890/070037

York, A. M., and M. L. Schoon. 2011. Collective action on the western range: coping with external and internal threats. International Journal of the Commons 5:388-409. 